\title{
Physiology and immunity of the invasive giant African snail, Achatina (Lissachatina) fulica, intermediate host of Angiostrongylus cantonensis
}

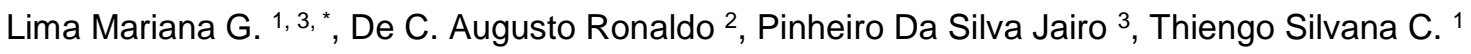

\author{
${ }^{1}$ Laboratório de Referência Nacional para Esquistossomose - Malacologia, Instituto Oswaldo \\ Cruz/FIOCRUZ, Rio de Janeiro, Brazil \\ 2 UMR 5244 Univ Perpignan via Domitia-CNRS-IFREMER-Univ Montpellier, Interactions Hôtes- \\ Pathògenes-Environnements (IHPE), Université de Perpignan via Domitia, France \\ 3 Área de Biofísica, Departamento de Ciências Fisiológicas, Instituto de Biologia, Universidade Federal, \\ Rural do Rio de Janeiro, Seropédica, RJ, Brazil
}

* Corresponding author : Mariana G. Lima, email addresses : maribiorural@gmail.com ; mariana.lima@ioc.fiocruz.br

ronaldo.augusto@univ-perp.fr ; jps@ufrri.br ; jairopinheirodasilva@gmail.com ; vinnytunholi@yahoo.com.br ; sthiengo@ioc.fiocruz.br ;

\begin{abstract}
:
As one of the most successful invasive land snail species, Achatina (Lissachatina) fulica Bowdich, 1822 has achieved wide global distribution, particularly in (sub)tropical regions, with further dispersal likely due to climate change. This species of giant African snails (up to $17 \mathrm{~cm}$ shell length) is a pest that has extensive negative impact on agriculture and can serve as vector for several parasites, including Angiostrongylus cantonensis, a nematode parasite that causes (human) eosinophilic meningitis, an emergent disease. Investigation showed that $A$. cantonensis infection negatively impacts the metabolism of $A$. fulica by depleting polysaccharide stores of the intermediate host, compromising the energy balance of the snail. A review of the literature indicates that $A$. fulica possesses potent innate type immune defenses to counter infection, including phagocytic hemocytes capable of deploying reactive oxygen species and lectins for non-self recognition, a serine protease-dependent coagulation response (not observed in other taxa of gastropods), as well as antimicrobial proteins including achacin, an antimicrobial protein. A recent chromosome level genome assembly will facilitate progressively detailed characterization of these immune features of $A$. fulica. We strongly encourage further immunological studies of $A$. fulica, ranging from organismal level to molecular biology to gain better understanding of the A. fulica internal defense response to nematode pathogens like $A$. cantonensis and the contribution of immune function to the invasiveness of (snail) species. Characterization of immunity of $A$. fulica, representing the understudied Stylommatophora (panpulmonate landsnails) will also broaden the comparative immunology of Gastropoda.
\end{abstract}




\section{Highlights}

- The giant African snail Achatina fulica, the most widely distributed invasive pest land snail, will likely disperse further with climate change. - Achatina fulica is intermediate host for the nematode Angiostrongylus cantonensis that causes eosinophilic meningitis. - Study of metabolic and immunological aspects of this parasite host provide better understanding of epidemiology and inform on comparative immunology of gastropods.

Keywords : Achatina fulica, immunology, physiology, nematodes, Angiostrongylus cantonensis 
Gastropoda comprises the largest Class of Mollusca, occurring in a wide variety of aquatic and

42 terrestrial habitats, showing a great diversity in anatomical structure. Accordingly, gastropods have contended

43 with many diverse pathogens, including opportunists and several phylogenetic lineages of specialized

44 eukaryotic parasites such as the digenetic trematodes (Loker, 2018; Arkitips et al., 2008). Considering the

45 framework of great species richness and diversity of lifestyles, gastropod immunology is likely highly diverse

46 due to lineage-specific evolution of novel features or modification and/or loss of ancestral aspects of immune

47 function (e.g. Gorbushin, 2019). To date, however, immune function has been studied consistently in only a

48 modest number of gastropod species (e.g. Schultz and Adema, 2017) that does not validly represent the

49 phylogenetic diversity of gastropods.

\section{1.1. Achatina fulica, a prominent invasive pest.}

Importantly, comprehensive understanding of immunology is especially lacking for air breathing

52 terrestrial slugs and snails that belong to the order Stylommatophora within the clade of Eupulmonata

53 (Gastropoda, Euthyneura, Heterobranchia). The stylommatophorans comprise of Scolodontidae (a small basal

54 group) and two large clades of non-achatinoid and achatinoid snails (e.g. Wade et al., 2006, Saadi and Wade,

55 2019). The latter clade includes the family Achatinidae of medium to large sized tropical land snails, native to

56 the African continent, that contains the subject of this review. Achatina (Lissachatina) fulica Bowdich, 1822.

57 Currently A. fulica is included within the subgenus Lissachatina and some but not all recent publications (e.g.

58 Borrero et al., 2009; Guo et al., 2019) have treated Lissachatina as a genus; however, at present, no published 
taxonomic works are available to sustain this treatment. This review will employ the binomial Achatina fulica. This species, commonly named the giant east African snail grows to large adult size (shell length up to $17 \mathrm{~cm}$ ). Like other giant African snails, A. fulica is considered a food source and a pet animal, and it may be applied in traditional medicine for antibacterial activity of secreted snail mucus (Etm et al., 2016). A few (or even single) A. fulica are capable of colonize new habitats; they are hermaphrodites that can self-fertilize and have a high reproductive output. It is known to consume more than 50 species of tropical plants, agricultural and horticultural crops, modify habitats and outcompete native snails in newly colonized non-native ecosystems (Raut and Barker, 2002), by predation and herbivory. It is of note that A. fulica impacts humans severely as a general nuisance, since snails populations may reach very high densities (Mead, 1961; Thiengo et al., 2007; Hoxha et al., 2019).

These factors, along with trends of cross-border migration and trading, have likely contributed greatly to transport and introduction of A. fulica outside traditional native distribution ranges, allowing this snail to emerge as an invasive alien species (Knobler et al., 2006). While fortunately, it seems that only a modest proportion of introduced organisms possesses the phenotypic plasticity of relevant traits for behavior and fitness needed to become an invasive species (Richardson et al., 2000; 2006), several species of terrestrial gastropods have been able to invade and establish in a wide variety of new ranges, including natural zones like the Amazon Rainforest and large urban agglomerations worldwide (Ruiz and Carlton, 2003; Roda et al., 2016; Hoxha et al., 2019). Classified among the 100 worst invasive pests in the world (Lowe et al., 2004), A. fulica is considered the most widely introduced and invasive land snail species pest with particular impact in tropical and subtropical regions. This may be exacerbated by climate change as this may lead to range expansion of invasive species and interact synergistically with invaders to further worsen the impact on local ecosystems (Rekha Sarma et al., 2015; ; Bellard et al., 2012; Lowe et al., 2000; Raut and Barker, 2002). Concerning the invasive colonization of the Americas, A. fulica was initially introduced from Hawaii (where it persists to date) to Florida, mainland of the USA in 1966 (Robinson, 1999; Kim et al., 2014). In the Caribbean, A. fulica was established by 1984 on the island of Guadeloupe, by 1988 on Martinique and subsequently on Barbados and Saint Lucia according to Raut and Baker (2002). More recently, A. fulica was reported from Jamaica and Haiti 
by Lindo et al., (2002) and Raccurt et al., (2003), respectively. Since initial reports from the 1980s, A. fulica has been reported from many countries in South America including Argentina (Gutiérrez Gregoric et al., 2011), Colombia (De la Ossa-Lacayo et al., 2012); Ecuador (Correoso Rodriguéz, 2006), Paraguay (Vogler et al., 2013), Peru (Borrero et al., 2009) and Venezuela (Martinez-Escarbassiere and Martinez, 1997). In Brazil, A. fulica was first introduced deliberately in 1988 in the southern state of Paraná (Teles and Fontes, 2002), where snails (probably from Indonesia) were sold at an agricultural fair as food resource for human consumption. Nowadays, A. fulica occurs in 25 out of the 26 states and the Federal District of Brazil (Morassutti et al., 2014; Thiengo and Fernandez, 2013; 2016).

Achatina fulica is very difficult to control once established; eradication has proven virtually impossible, especially in developing countries. In excess of $\$ 1$ million dollars were spent for (ongoing) counter measures against $A$. fulica during the initial five years after this invasive snail species established in Florida (USA), (see e.g. Mead, 1961; Prociv et al., 2000; Raut and Barker, 2002; Thiengo et al., 2010). To date, it is illegal to import or keep A. fulica in the USA (see https://www.aphis.usda.gov/aphis/ourfocus/planthealth/plant-pest-anddisease-programs/pests-and-diseases/giant-african-snail/gas) and control efforts include chemical phytosanitary treatment of agricultural products to be shipped out of quarantined areas. Molluscicide treatments of A. fulica habitats can significantly inhibit snail development and reduce transmission of the parasites that these snails harbor (Gomot-de Vaufleury and Bispo, 2000). Unfortunately, the efficacy of molluscicides varies (Hallman 2011; 2016), and intensive use has a negative environmental impact as it leads to chronic soil contamination (Jansch et al., 2006; Arias-Estévez et al., 2008; Thiengo et al., 2007).

\section{2 - Achatina fulica, vector of parasitic nematodes.}

Another negative aspect of invasion of new ranges by A. fulica is that this snail may transmit or even introduce pathogens with undesirable health and socioeconomic effects. Like several other species of land snails that harbor parasites, e.g the widely distributed brown garden snail Cоrnи aspersum (Müller, 1774; formerly Helix aspersa), vector of the nematodes Angiostrongylus vasorum and Aelurostrongylus abstrusus (Druart et al., 2011; Di Cesare et al., 2015); Theba pisana (Müller 1774), the white garden snail present in Australia, Israel, 
and USA), intermediate host for the nematode lungworm Muellerius capillaris and the trematode Brachylaima cribbi (Baker, 1986; Butcher and Grove, 2001; Grewal et al., 2003), also A. fulica snails may spread plant

112 pathogens and they are intermediate host of several parasitic nematodes, such as Aelurostrongylus abstrusus, Phasmarhabditis hermaphrodita, Rhabditis sp, Strongyluris sp (Turner, 1967; Alicata, 1991; Zanol et al., 2010; Williams and Rae, 2015; Oliveira and Santos, 2018). Importantly, A. fulica is also vector of two zoonotic nematodes: Angiostrongylus costaricensis, causing abdominal angiostrongyliasis and the congeneric rat lungworm, Angiostrongylus cantonensis, which causes eosinophilic meningoencephalitis (or the rat lungworm disease) in humans (Alicata, 1991; Prociv et al., 2000; Carvalho et al., 2003; 2012). Abdominal angiostrongyliasis appears to be restricted to the Americas, with reports ranging from the southern United States to northern Argentina (Graeff-Teixeira, 2007). Originally endemic in Southeast Asia and Pacific Islands, to date, eosinophilic meningitis has been reported from about 30 countries of all continents with exception of Europe and Antarctica (Cowie, 2013a). In Hawaii, A. fulica has been associated with transmission of eosinophilic meningoencephalitis (Kim et al., 2014).

The life cycle of A. cantonensis involves rodents as definitive hosts and several species of terrestrial and freshwater snails that may serve as intermediate hosts. Gastropods become infected by ingestion of rodent feces that contain A. cantonensis larvae ( $\mathrm{L}_{1}$ stage). Inside the snail, the parasite molts twice over about 15 days. The resulting $L_{3}$ larvae are directly infective for the definitive host (Cheng and Alicata, 1965; Maldonado et al., 2010) but an optional role for paratenic (carrier) hosts such as land crabs, freshwater prawns, fish, frogs and planarians increases the chances for transmission of the parasite. Angiostrongylus costaricensis has a similar life cycle but does not employ paratenic hosts (Morera, 1973; Spratt, 2015).

Human Angiostongylus infections result from ingestion of raw gastropods or paratenic hosts (in case of A. cantonensis) that harbor $\mathrm{L}_{3}$ nematode parasites, or by food that was contaminated with $\mathrm{L}_{3}$ larvae from decayed, disrupted snail bodies or perhaps shed from infected snails (Graeff-Teixeira et al., 2009). Because humans are not natural definitive hosts, neither Angiostrongylus species is able to complete their life cycle; parasite eggs or larvae are not released into the feces and this makes diagnosis difficult. Although the parasites do not survive long in humans, infection causes uncomfortable symptoms including nausea, vomiting, neck 
stiffness, fever and headaches. Occasionally, patients develop complications that lead to intestinal obstruction and perforation (A. costaricensis) or neurological damage (A. cantonensis) and even death.

Both A. costaricensis and A. cantonensis show low specificity for intermediate hosts; many different species of terrestrial and aquatic (fresh water) gastropods with natural Angiostrongylus infection have been observed around the world (Wallace and Rosen, 1969a; Malek and Cheng, 1974; Carvalho et al., 2012; Thiengo et al., 2010; Kim et al., 2014). The introduced snail species A. fulica and South American ampullariid Pomacea canaliculata (Lamarck, 1822) are the main intermediate hosts of A. cantonensis in the south of China (Lv et al., 2011), and an extensive list of molluscs transmits angiostrongyliasis on the Hawaian Islands (Kim et al., 2014). From Brazil, reports of natural intermediate host molluscs (Morassutti et al., 2014; Thiengo and Fernandez, 2016) include various terrestrial pulmonates (Stylommatophora): Belocaulus willibaldoi Ohlweiler, Mota and Gomes, 2009, Bradybaena similaris (Férussac, 1821), Sarasinula linguaeformis (Semper, 1885) (=Sarasinula marginata according to Thomé, 1989), Subulina octona (Bruguière, 1792) and A. fulica. Transmission of $A$. cantonensis was also reported for another ampullariid Pomacea lineata (Spix in Wagner, 1827), in northeast Brazil (Thiengo et al., 2010).

In the laboratory, the life cycle of both A. cantonensis and A. costaricensis has been maintained through experimental infection of Biomphalaria glabrata (Say, 1818) a freshwater pulmonate snail (Richards and Merritts, 1967; Tunholi-Alves et al., 2011; Bonfim et al., 2018). Taking in account the epidemiology of eosinophilic meningitis transmission, reports of A. fulica infected with A. cantonensis in 33 municipalities from 11 different Brazilian states (Thiengo and Fernandez, 2016; Cognato et al., 2016), and that the widely distributed A. fulica snails usually occur in dense populations which favors the contact of people with the parasite, A. fulica is considered the main vector for Angiostrongylus-associated eosinophilic meningitis in Brazil. Study of snail physiology, parasitology and immunity will likely provide inroads for improved or novel control strategies to extend the options to mediate the overall impact of invasive A. fulica

\section{3 - Impact of nematode infection on Achatina fulica physiology.}


Study of the physiology of infected snails revealed the burden of A. cantonensis infection upon A.

162 fulica. Regulation of energy metabolism is essential for biological functions and the maintenance of life (Fraga

163

164

165

166

167

168

169

170

171

172

173

174

175

176

177

178

179

180

181

182

183

184

185

et al., 2013). In pulmonate gastropods, including A. fulica, this regulation centers around availability of carbohydrates, deposited as glycogen and galactogen in special storage cells that are located in the mantle, among the digestive gland acini, the gonads, and also the muscular tissue of the cephalopedal mass (Joosse, 1988; Joosse and van Elk, 1986; Tunholi-Alves et al., 2014; Tunholi et al., 2013; Pinheiro and Amato, 1994). During physiological stress conditions, such as caused by parasite infection, the carbohydrate reserves are mobilized to make glucose available as substrate to oxidative metabolism for production of ATP. This involves a complex activation process, including glycogenolysis and components of oxidative respiration; glycolysis, the tricarboxylic acid (TCA) cycle, and oxidative phosphorylation (Tunholi-Alves et al., 2014; Massa et al., 2007; Bezerra et al., 1997).

Alterations in this carbohydrate metabolism have been recorded from infected snails using different snail host-larval parasite systems, and glycemia is generally reduced significantly (Becker, 1980; El-Ansary et al., 2000; Lima et al., 2016, 2017; Martins et al., 2018). Larval helminths absorb glucose from snail hemolymph as substrate for ATP generation in support of the parasite metabolism and the development of intramolluscan larvae (Becker, 1980).

Demonstration of glycolytic enzyme activities provided evidence that oxidative pathways exist in larval A. cantonensis (Shih and Chen, 1982). The competition by the parasite for nutrients causes a physiological state in the snail hosts that is similar to starvation (Pinheiro et al., 2009). Brockelman and Sithithavorn (1980) first described changes in the carbohydrate metabolism of A. fulica snails following experimental infection with $A$. cantonensis. Initially, the glucose content of the snail hemolymph was significantly reduced during the prepatent infection, returning to normal values after one week. Tunholi-Alves et al., (2018) showed that reduction of glucose levels was associated with depletion of glycogen deposits in the digestive gland and cephalopedal mass of A. cantonensis-infected A. fulica. Along with similar observations from another parasitized snail species, B. glabrata harboring A. cantonensis (Tunholi-Alves et al., 2014), this demonstrates the existence of 
homeostatic mechanisms that rely on mobilization of tissue stores of carbohydrate (glycogen and galactogen) to recover and maintain glycemia levels in snail hemolymph.

Parasite load (intensity of infection) influences the extent to which the oxidative metabolism of A. fulica is altered by A. cantonensis, as revealed by different degrees of impact on activities of hexokinase (HK) and lactate dehydrogenase (LDH), catalytic enzymes that are linked the oxidative metabolism of the snail host. The activity of HK, catalyst of the first step of glycolysis, increased significantly (relative to controls) when A. fulica was infected with $\geq 2,500\left(\mathrm{~L}_{1}\right)$ A. cantonensis larva. Accompanied by reduced glucose levels, heightened HK activity reflects an increased energy (ATP) demand in the A. fulica host, warranted by the need to maintain basic vital processes in the presence of developing larval A. cantonensis (Tunholi-Alves et al., 2014). Depending on parasite load, A. cantonensis causes yet additional subsequent changes in the oxidative metabolism of A. fulica.

Snails infected with fewer than $10,000 \mathrm{~L}_{1}$ larvae develop significant reductions of pyruvate and oxaloacetate. These changes may be due to either (I) accelerated redox reactions of the TCA cycle to support increased demand for ATP that challenge snail metabolism, causing a shortfall in the adequate supply of critical TCA intermediates, like oxaloacetate (substrate for the first reaction of the TCA cycle) or (II) the shunting of oxaloacetate away from the TCA cycle to drive gluconeogenesis for production of glucose using non-glycemic substrates in an attempt to restore normoglycemia (Tunholi-Alves et al., 2014). Furthermore, A. fulica snails that received high infective doses $\left(10,000\right.$ and $15,000 \mathrm{~L}_{1}$ larvae) of $A$. cantonensis (Tunholi-Alves et al., 2018) showed significant increases in activity of LDH (key enzyme for anaerobic respiration), along with lactate accumulation and decreased levels of pyruvate in the hemolymph, indicating a transition of the oxidative metabolism from aerobic to anaerobic during infection, similar to results obtained with chromatographic and spectrophotometric methods for Biomphalaria harboring A. cantonensis (Lima et al., 2016). The activation of anaerobic metabolism (LDH), enables continued production of energy (ATP), avoids inhibition of the glycolysis pathway by increased pyruvate levels, facilitates availability of NAD+ (oxidized electron carrier), and supports formation of intermediate metabolites that are needed for the survival of the host and for parasite development (Lima et al., 2016). 
Ultimately, prolonged infection (especially with high parasite load), leads to depleted carbohydrate deposits that cause the snail metabolism to use alternative substrates as energy source, leading to breakdown of lipids (Tunholi-Alves et al., 2011a) and proteins (Tunholi-Alves et al., 2012). Direct absorption of amino acids by developing larval A. cantonensis may further reduce protein levels; higher infection loads led to increasingly lower protein concentrations in A. fulica (Tunholi-Alves et al., 2015). The carbon backbone of proteins supplies intermediate compounds for neoglucogenesis but continued protein degradation not only reduces protein concentration but also leads to elevated levels of nitrogen compounds, altering the chemical composition of snail host hemolymph (Pinheiro et al., 2009). The excretion as urea, uric acid or ammonia, of amino groups that result from deamination, challenge the water balance of A. fulica, a terrestrial gastropod (Tunholi-Alves et al., 2014). While specific data from A. fulica are not available, Angiostrongylus infections may reduce the lifespan of snail hosts (Wallace and Rosen, 1969c).

\section{4 - Immunity of Achatina fulica}

Despite considerable initial investigative attention from comparative immunologists, general aspects of the immune function in A. fulica are interpreted largely by considering findings from several other gastropod species, as presented in section 4.1. This is with the realization that some aspects of immune defense will be lineage-specific, however, the sharing of several immune features across animal evolution and the commonalities evident among immune defenses of phylogenetically diverse gastropods motivate reasonable confidence that this approach is generally informative. For example, a limited diversity of types of AMPs characterizes gastropods of both the Planorbidae and Physidae (sister families within the Hygrophila, Panpulmonata), and caenogastropods share particular categories of immune lectins with panpulmonate snails (Loker et al., 2004; Gorbushin and Borishova, 2015; Gorbushin, 2019; Schultz et al., 2018). Likewise, the available insights specifically regarding A. fulica immunity (4.2) include antimicrobial proteins found throughout the gastropod clade, as well as a capacity for hemolymph coagulation not found in hygrophilid panpulmonates. It is of note that immunological studies of $A$. fulica have employed mostly cell biology and 
common in the "omics"-era. In light of resurging interest in A. fulica, also for the reasons provided in this review (Penagos-Tabares et al., 2018), such data may be anticipated in the near future.

\section{1 - General consideration of gastropod host-pathogen immune interactions.}

Historically, studies of gastropod immunity have largely focused toward immune interactions between aquatic vector snails and digenetic trematodes, such as the medically relevant schistosomes, with occasional consideration of other (microbial) pathogens (Adema et al., 2009; DeLeury et al., 2012; Loker and Bayne, 2018).

Snail immune systems, like those of other invertebrates (Murthy and Ram, 2015) do not include vertebrate-type acquired immunology but comprise highly effective innate immune mechanisms. Immune function can be selective, allowing mutualistic interactions between gastropods and microbiota; commensal communities of bacteria and fungi can be instrumental in adaptation and evolution by affecting multiple fitness parameters of the host (Soen, 2014), even viruses can modulate host-parasite interactions in invertebrates (Galinier et al., 2017). Normally, however, (opportunistic) pathogens are countered by potent internal defenses. Actual immune-elimination by snails of metazoan parasites such as digenetic trematodes depends on complex interactions between determinants of compatibility. First, snail immune receptors must be able to recognize the antigens of the invader in order to activate host defenses. Intra-individual polymorphisms of such receptors and antigens determine matched versus mismatched status of host and parasite phenotypes, resulting in either survival or immune-elimination of the parasite (Mitta et al., 2017). Secondly, host immune systems may be negated by anti-effector strategies of the parasite (Lie, 1982).

These interactions play out in a continuous arms race that drives evolution of (mechanisms that generate) diversity and polymorphism of the factors that determine the outcome of the host-parasite interplay (Combes, 2000; Gourbal et al., 2015). For instance, antigenic variation is a common strategy of eukaryote pathogens to evade a host immune response (Finlay and McFadden, 2006; Perrin et al., 2013).

Absent the vertebrate-specific rearranging genes that yield specific immune receptor mechanisms (Di Noia and Neuberger, 2007; Tonegawa, 1983), the remarkable effectiveness of invertebrate immune function is 
underscored by the evolutionary success of invertebrates (Pinaud et al., 2016). Evidence has mounted that also invertebrates, and gastropods specifically, are capable of considerable diversification of innate-type immune receptors and possess forms of immune memory to effectively counter diverse pathogens (Zhang et al., 2004, Ghosh et al., 2010; Müller et al., 2017; Netea et al., 2011; Wang et al., 2013; Pinaud et al., 2016).

Snail immune defenses include the body surface as external physical barriers, chemically fortified by (mucus) secretions containing antimicrobial factors. Pathogens that penetrate through these defenses encounter lytic factors, antimicrobial proteins and peptides (AMPs) in tissues and hemolymph. The antimicrobial bacterial pathogen-associated molecular patterns (PAMPs; also referred to as microbe-associated molecular patterns: MAMPs) or damage-associated molecular patterns (DAMPs) are recognized by pattern recognition receptors (PRRs). The PRRs are highly diverse, comprising secreted molecules, cell surface- and cytoplasmic receptors (Schmitt et al., 2011; Escoubas et al., 2015). Among soluble receptors are Gram-negative bacteria-binding protein (GNBP), peptidoglycan recognition protein (PGRP) and a variety of lectins, including fibrinogen-related proteins (FREPs) (Escoubas et al., 2015, Gorbushin, 2019). Cell surface receptors like Toll-like receptors (TLRs) and scavengers receptors (SRs) are highly conserved evolutionarily (Peiser et al., 2002; Sarrais et al., 2004), just like cytoplasmic receptors from the RIG-I-like helicase (RLH) family and nucleotide-binding oligomerization domain (NOD)-like receptors (Sirrad et al., 2007; Yoneyama and Fujita, 2007; Barber, 2011). PPR-binding leads to coagulation, (direct) opsonization, triggering of proteolytic enzyme cascades that produce toxic compounds, or initiates intracellular signaling to activate immune defense cells to exert cytotoxicity (van der Knaap et al., 1983; Janeway, 1994; Lacchini et al., 2006, Hanington et al., 2010; Le Clec'h et al., 2016).

The cellular mediators of gastropod immunity are circulating macrophage-like phagocytic immune cells, named hemocytes, capable of production of cytolytic molecules including reactive intermediates of oxygen and nitrogen, as well as of phagocytosis and encapsulation of pathogens (Levine and Strand, 2002; Zanker, 2010). Hemocytes are the main effectors of the defense system but they are also involved in wound repair, nutrient transport, shell calcification, digestion and excretion processes (Cheng, 1996). Based on morphology, hemocytes are commonly classified into three main cell types: granulocytes, hyalinocytes and blast-like cells (Allam et al., 2015; Mahilim and Rajendran, 2008; Cavalcanti et al., 2012). Hemocytes bear yet 
additional surface receptors like integrins, SRs, and C-type lectins (Liu et al., 2011; Humphries and Yoshino, 2003) and will internalize pathogens (bacteria, fungi, and experimental particles like latex beads) through phagocytosis, larger targets such as larval helminth are encapsulated by multiple hemocytes. Little is known about the molecular processes involved in encapsulation (Ray et al., 2013; Queiroga et al., 2013; Francisco et al., 2010; Laruelle et al., 2002; Mladineo et al., 2012; Batista et al., 2009; Kawasaki et al., 2013; Wootton et al., 2006; Wang et al., 2012). increase with the intrinsic number of circulating hemocytes (Larson et al., 2014). The number of hemocytes in hemolymph varies between and within species (Adema et al.,1992), because of age, infection and under influence of physiological and environmental factors (Livingston and de Zwann, 1983). For the actual killing of pathogens, hemocytes produce and release lysosomal enzymes, antimicrobial peptides, reactive species hydrogen peroxidase, ROS and RNS (Loker, 2010; Schimitt et al., 2011). Continued research may broaden the perspective of general immune defenses, for instance an ancient and evolutionarily conserved host defense mechanism was revealed by the recent finding that animal immune cells may deploy their DNA as extracellular traps (ETs) to capture pathogens (Poirier et al., 2014; Robb et al., 2014). Relatively little is known about antinematode immunity in gastropods, however, literature indicates that snail species do not indiscriminately support the development of any nematode species that they may encounter (Dróźdź et al., 1971), however, several species of nematodes attract but most often do not appear to be eliminated by snail host immunity (Bayne, 1983). Further investigations may help clarify to what extent immune function is a codeterminant of vector suitability of a snail like A. fulica for A. cantonensis.

\section{2 - Immune features of Achatina fulica.}


of conserved antimicrobial proteins and that are more restricted like ability for haemolymph coagulation, that has not been observed from e.g. aquatic panpulmonate gastropods.

\subsection{1 - Shell encapsulation of nematodes.}

Exploration of the use of nematode infection as control measure against snail pests revealed that pathogen that is effectively against several other gastropod species. Starting at 3 days post exposure, inspection of experimental snails evidenced an immune response that involved the A. fulica shell. Infective $P$. hermaphrodita larvae are encapsulated, killed and remain permanently encased in the shell (Williams and Rae, 2015; 2016). This immune mechanism is effected by cells on the inner layer of the shell that adhere to the nematode cuticle, spread over the worm body to then fuse and encase the nematode to the inside of the shell. Remarkably, DNA extracted from shell-encased dead worms allows for PCR and sequence-based identification of the infecting nematodes. Follow-up investigation with experimentally exposed and field collected snails showed that this novel anti-nematode immune mechanism is shared by snail species of both achatinoid and non-achatinoid clades of the Stylommatophora (Rae, 2017).

\subsection{2 - Achacin}

In 1985, Kubota et al., isolated a protein with an antibacterial activity, composed of 70-80kDa subunits from the body surface mucus of A. fulica. Further characterization of this protein designated as Achacin yielded the first cDNA sequence from A. fulica ever deposited in GenBank (Obara et al., 1992). Achacin (purified or recombinantly expressed) inhibited growth of Gram-negative and Gram-positive bacteria, and it was shown to attack the surface membrane of bacteria but not directly cause lysis bacterial cells (Otsuka-Fuchino et al., 1992; 1993; Ogawa et al., 1999). The mode of antibacterial action of 
from toxins in snake venoms and experimentally demonstrated to result from oxidative deamination of amino acids, producing ketoacids, ammonia $\left(\mathrm{NH}_{3}\right)$ and hydrogen peroxide $\left(\mathrm{H}_{2} \mathrm{O}_{2}\right)$. Additional to generating toxic metabolites, also depletion of amino acids leading to reduction of available nutrients was proposed to contribute to the microbicidal activities of Achacin (Ehara et al., 2002). It is of note that Achacin presents a landmark discovery of comparative immunology of gastropods and molluscs. Starting with a report of Aplysianin from Aplysia kurodai (sea hare) an euopisthobranch gastropoda (Kamiya et al., 1986; Takamatsu et al., 1995), many additional LAAOs been recovered from several gastropod and other molluscs. Phylogenetic analyses distinguish molluscan LAAOs as a major subfamily separate from other animal LAAOs, such independent evolution indicates an important reliance of molluscs on LAOOs for innate immune function (Hughes, 2010; Suwannapan et al., 2018).

\subsection{3 - Mytimacin and other cytoloytic peptides from mucus.}

The body surface mucus of $A$. fulica contains multiple components with lytic activity additional to Achacin. Zhong et al., (2013) purified Mytimacin-AF, a cysteine-rich antimicrobial peptide (AMP) from the macin family. The cDNA sequence contains an open reading frame that encodes for an 80 amino acid-long peptide that has antimicrobial activity against fungi, Gram-negative and Gram-positive bacteria, particularly Staphylococcus aureus. A search for potential anticancer peptides motivated a broad survey of novel lytic factors present in A. fulica mucus. Bioinformatics analyses of mass spectrometry data obtained from two HPLC-fractions of mucus that displayed lytic activity toward in vitro cultured primate epithelial cells and (human) cancer cells, predicted another 16 lytic peptides in silico (E-Kobon et al., 2015). The lack of sequence similarity of predicted lytic peptides with existing entries in public sequence databases, suggest that these mucus-derived lytic peptides have not been encountered previously, but was also considered to reflect the limited availability of sequence data from mollusc, especially the stylommatophoran land snails, especially (E-Kobon et al., 2015).

\subsection{4 - Lectins}



Borushova, 2015), it was not surprising that initial searches for agglutinins as mediators of non-self

363 recognition in A. fulica led to identification of several (mucus and) hemolymph lectins, each with different carbohydrate specificity (Basu et al., 1986; Mitra and Sarkar, 1988; Sarkar et al., 1984; Mitra et al., 1988). Relative levels of lectin-mediated hemagglutinating activity increase with age of A. fulica snails (Baskakov et al., 2000), indicating a maturation of immune function from juvenile to adult $A$. fulica. Befitting the technological capabilities at the time of these pioneering studies, these lectins were identified only by carbohydrate specificity and the molecular weight of biochemically purified (subunits of) proteins, sequence characterization has remained pending, to date. Functional aspects, however, have been studied in greater detail for two lectins.

The first is an abundant hemolymph lectin of A. fulica, designated as C-reactive protein (CRP) based on cross-reactivity with antisera to CRP protein of the horse shoe crab Limulus polyphemus (Agrawal et al., 1990) and specific binding of phosphoryl choline, a trait shared with CRPs (members of the pentraxins), innate immune proteins from both invertebrate and vertebrate animals, (Mandal et al., 1991). The aminoacid content was determined and A. fulica CRP (a multimeric protein of 400kDa) was found to be heavily glycosylated (30-40\% carbohydate), but no nuclueotide sequence is currently available. Agglutinating activity was enhanced in the presence of calcium-ions (Mandal et al., 1991). The CRP of A. fulica is multifunctional, with bacteriostatic activity for Gram (-) bacteria and bactericidal activity for Gram (+) bacteria, likely through ROS production and induction of apoptosis, and it may serve to protect the snail against toxicity from heavy metals (Mukherjee et al., 2014; Bose and Bhattacharya, 2000).

Secondly, research has also focused on Achatinin (Basu et al., 1986). This (9-O-AcSA)-specific hemolymph lectin (242 kDa, subunits of $15 \mathrm{kDa}$ ) is expressed in the albumen gland (Sen et al., 1992) and in hemocytes (Biswas et al., 2000), binds sialic acid-epitopes on LPS in a calcium-dependent manner and is bacteriostatic toward Gram-negative Escherichia coli. Remarkably, Achatinin is also multifunctional, 
additional to antimicrobial activity, LPS binding of this PRR also activates other aspects of A. fulica immunity as is described in the next section.

\subsection{5 - LPS-mediated coagulation.}

Bacterial LPS activates a defense response in A. fulica hemocytes that involves the release of several interactive proteins into the hemolymph that orchestrate a coagulation reaction; gel formation to aggregate and sequester bacteria. This response is highly reminiscent of well-characterized endotoxindependent plasma coagulation from the horseshoe crab Limulus polyphemus, resulting from an enzyme cascade that employs zymogens and serine proteases released by amboecytes that degranuate in response to detection of LPS.

The coagulation reaction of A. fulica can be affected in vitro with the protein lysate of snail hemocytes (Biswas and Mandel, 1999). The name of this preparation, "Achatina amboecyte lysate (AAL)" may seem less intuitive because it employs the alternative designation of amoebocyte for hemocyte. Protein biochemical analysis implicated Achatinin as major, important component of AAL. Depletion of Achatinin reduced the coagulation activity of AAL by $77 \%$. Additional to lectin function (LPS binding), Achatinin also has enzymatic serine protease activity that is critical for the coagulation, as shown by sensitivity of this reaction to protease inhibitors (Biswas et al., 2000). heparin affinity chromatography. ESF differs from Achatinin by a native molecular weight of $140 \mathrm{kDa}$ (consisting of two non-covalenty bound $70 \mathrm{kDa}$ subunits), and although both of these immune factors bind LPS, ESF is activated by alpha-chymotrypsin instead of endotoxin. Again, the use of specific inhibitors showed that active ESF functions a serine protease (Biswas et al., 2000). It is of note that the endotoxin-dependent coagulation reaction of A.fulica may be unique to Achatinoid gastropods (e.g. Archachatina marginata, Salawu et al. 2011) or to (larger taxonomic subsets of) the Stylommatophora; it has not been reported fresh water pulmonate snails (Hygophila) like the well studied B. glabrata a main model for gastropod immunity. Along with characterization of all AAL factors and the mechanism of the 
protein cascade needed for coagulation, the phylogenetic distribution of this immate immune response merits further investigation.

413

\subsection{5 - Hemocytes}

The hemolymph of A. fulica can easily be sampled by heart puncture, a procedure that can be survived by the snail. Microscopical observation delineated two categories of cell types among glass-adherent hemocytes; granulocytes and agranulocytes (Adema et al., 1992), generally corresponding with hemocyte types recognized in other gastropods (Yoshino, 1976; Barraco et al., 1993). Karuthapandi (2010) revealed that the total hemocyte count of active A. fulica snails was higher than that of the snails that aestivated. The granulocytes of A. fulica sub categorized into granulocyte I, granulocyte II and granulocyte III. Only few round small cells with high nucleus to cytoplasm ratio were observed. Overall, agranulocytes and granulocytes were proportioned at an $80 \% / 20 \%$ ratio in the hemolymph of A. fulica, without evidence of sesonal variation. Differential hemocyte counts revealed only modest variation in the percentage of agranulocytes, granulocyte I and granulocyte III of active versus aestivated snails, whereas the percentage of granulocyte II was higher in aestivated A. fulica relative to active snails (Karuthapandi, 2010), perhaps due to the difference in metabolic state, especially food uptake.

Basic immune functions of A. fulica hemocytes as snail defense cells were demonstrated in vitro by phagocytosis of zymosan particles and production of ROS (Adema et al., 1992). More recently, an in vitro coculturing assay that was designed to investigate the cellular immune interactions of stylommatophoran snails with $A$. cantonensis shows that $A$. fulica hemocytes attach to nematode larvae and proceed to hemocyte clusters around the parasites (Penagos-Tabares et al., 2018). The same study and work from Lange et al. (2017) also observed that hemocytes from A. fulica, as well as Arion lusitanicus and Limax maximus (gastropod species commonly referred to as slugs) deploy DNA-rich extracellular aggregates refered to as invertebrate extracellular phagocyte traps (InEPTs) similar to the phagocyte-derived extracellular traps (ETs) described from vertebrates catching larvae and decreasing their motility. It was proposed that hemocyte InEPTosis immobilizes nematodes to hamper migration of the larvae through the tegument or body and further facilitate exposure of the entrapped 
parasites to cell-mediated cytotoxicity of additional hemocytes. The long-term fate of the parasites remains to

437 be determined.

438

\section{5 - Achatina fulica, entry into the omics era.}

As described above, study of A. fulica has not only provided some of the earliest insights into general aspects of gastropod immunity but also continues to contribute to a more comprehensive overview of innate immunity in invertebrates. A continued reliance, mostly on cellular and biochemical research approaches has provided a steady yet rather slow progress in characterization of immune function of A. fulica, and of stylommatophoran snails as a larger, important group within the Gastropoda. The lack of specific sequence data to define the factors that enable the fascinating immune processes recorded from A. fulica hinders comparative approaches that can reveal the phylogenetic distribution of unique and shared defense capabilities across gastropods. Increasingly, routine and accessible next generation sequencing (NGS) technologies are now available to explore the genome sequences and transcriptomes from non-model organisms. While it remains challenging to derive high quality assemblies, extensive genome sequence and RNAseq data can be analyzed using computational bioinformatics for (potential) immune genes to indicate presence of immune mechanisms within an organism relative to the phylogenetic position. The validity of this approach (Dheilly et al., 2014, Schultz and Adema, 2017) is underscored by a broader view of immune function in a specific gastropod like $B$. glabrata (Adema et al., 2017) and the modeling of shared lectin-based complement-like system that serves immunity across the Mollusca and other protostome invertebrates (Gorbushin, 2019). Molecular level approaches have more usually been applied for population biology (e.g. Ayyagari and Sreerama, 2017; Fontanilla et al., 2014), but recently, the genome of A. fulica has become accessible with the publication of both the 15,057bp mitochondrial genome (He et al., 2016) and the nuclear genome (Guo et al., 2019) the first to represent the stylommatophoran gastropods. The genome (estimated at $2.12 \mathrm{~Gb}$ ) of a single A. fulica snail from the Guangxi region of China was sequenced to yield a publicly available high quality, chromosomal-level genome assembly of $1.85 \mathrm{~Gb}$ with a contig N50 length of $726 \mathrm{~kb}$. The predicton of 23,726 protein-coding genes will be of great value to facilitate proteomics level studies. It is anticipated here that this significant data 
resource will lead to sequence characterization of immune factors previously identified from A. fulica through

462 biochemical parameters only, like Achatinin, ESF and others, also providing provide a wide-ranging insight into related and additional immune genes in this snail species.

464

\section{6 - Conclusions and Future Prospects}

By phylogenetic identity alone, A. fulica merits investigative attention due to the potential as representative of a major branch of the Stylommatophora, to inform broadly on gastropod immune function. Already, A. fulica research has indicated both unique- and fundamental, evolutionary conserved aspects of snail immunity. The great biological and evolutionary diversity within the class Gastropoda of the phylum Mollusca makes it highly probable that particular clades of snails have evolved unique immune features. Importantly, broadening studies beyond the main focus on a very small segment of gastropod diversity indicated the possibility of differences in the elaboration of immune function between gastropod families. Schultz et al., 2017 observed that Physella acuta (Physidae, sister family of the Planorbidae) snails did not equally employ FREPs, a category of PPRs that is instrumental for coordinating immune elimination of schistosome parasites in the planorbid snail B. glabrata, vector of schistosomiasis (Hanington et al., 2012).

Renewed interests to study A. fulica are driven by the recognition of multiple negative biological properties that render this snail a highly effective invasive species that is recalcitrant toward eradication, a pest that can destroy (crop)vegetation and outcompete native species, and a potential vector that may transmit several parasites including A. cantonensis causative nematode pathogen for eosinophilic meningitis, an emerging infectious disease in humans. Elucidation of the underlying traits that determine the range if negative biological impact opens possibilities to develop strategies for control of A. fulica, or to mitigate, modify, or at least predict the distribution of the snail and associated parasite transmission.

A modest but strong tradition of biochemically centered investigations provides a several entry points for more detailed characterization of A. fulica immunity, with great potential to benefit from the recently available genome sequence data. We thus strongly encourage further immunological studies of the invasive nature of A. fulica, and interaction of A. fulica with A. cantonensis. In the process such studies will yield exciing 
new insights also in comparative immunology of terrestrial snails to reveal evolutionary patterns in the

evolution of immune function of Gastropoda.

\section{7- References}

Adema C.M., Mohandas A., van der Knaap W.P.W., Sminia T., 1992. The effect of homolymph extraction on distribution of lysosomal enzymes in Lymnea stagnalis: a cytochemical study. Comp. Hemotol. Int. 2, 61-67.

Adema C.M., Hillier L.W., Jones C.S., Loker E.S., Knight M., Minx P., Oliveira G., et al., 2017. Whole genome analysis of a schistosomiasis-transmitting freshwater snail. Nat Commun. May 16; 8:15451. doi: 10.1038/ncomms 15451

Adema C.M., Hanington P.C., Lun C.M., Rosenberg G.H., Aragon A.D., Stout B.A., Lennard Richard M.L., Gross P.S., Loker E.S., 2009. Differential transcriptomic responses of Biomphalaria glabrata (Gastropoda, Mollusca) to bacteria and metazoan parasites, Schistosoma mansoni and Echinostoma paraensei (Digenea, Platyhelminthes). Mol Immunol. 47, 849-60. doi: 10.1016/j.molimm.2009.10.019.

Alicata J. E., 1991. The discovery of Angiostrongylus cantonensis as a cause of human eosinophilic meningitis. Parasitol. Today. (Regul Ed) 7, 151-153.

Allam, B., Raftos, D., 2015. Immune responses to infectious diseases in bivalves. J. Invertebr. Pathol. $131,121-136$.

Arias-Estévez M., López-Periago E., Martínez-Carballo E., et al., 2008. The mobility and degradation of pesticides in soils and the pollution of groundwater resources. Agricul. Eco. Environment 123, 247260. DOI: 10.1016/j.agee.2007.07.011

Aktipis S.W., Giribet G., Lindberg D.R., et al., 2008. Gastropoda an overview and analysis, in: Ponder WF, Lindberg DR, (Eds.) Phylogeny and Evolution of the Mollusca. Berkeley: University of California Press. 201- 237.

Ayyagari V.S., Sreerama K., 2017. Evaluation of haplotype diversity of Achatina fulica (Lissachatina) [Bowdich] from Indian sub-continent by means of $16 \mathrm{~S}$ rDNA sequence and its phylogenetic relationships with other global populations. Biotech. 7(4):252. doi: 10.1007/s13205-017-0877-4.

Barber, G.N., 2011. Innate immune DNA sensing pathways: STING, AIMII and the regulation of interferon production and inflammatory responses. Curr. Opin. Immunol. 23, 10-20.

Baker G.H., 1986. The biology and control of white snails (Mollusca, Helicidae), introduced pests in: Australia. Commonwealth Scientific and Industrial Organization, [Melbourne], Australia.

Barraco M.A., Steil, A.A., Gargioni R., 1993. Morphological characterization of the hemocytes of the pulmonate snail Biomphalaria tenagophyla. Mem. Inst. Oswal do Cruz. 88, 73 - 83. 
Basu S., Sarkar M., Mandal C., 1986. A single step purification of a sialic acid binding lectin (AchatininH) from Achatina fulica snail. Mol Cell Biochem. 71,149-57.

Batista, F.M., Boudry, P., Dos Santos, A., Renault, T., Ruano, F., 2009. Infestation of the cupped oysters Crassostrea angulata, C. gigas and their first-generation hybrids by the copepod Myicola ostreae: differences in susceptibility and host response. Parasitology 136, 537-543.

Bayne C.J., 1983. Molluscan immunobiology. In: A.S.M.. Salleudin and K.M. Wilbur (Eds.), The Mollusca. 5. Physiology, Part 2. Academic Press Inc., New York, New York, 500p.

Becker W., 1980. Metabolic interrelationship of parasitic trematodes and molluscs, especially Schistosoma mansoni in Biomphalaria glabrata. Zeitschrift fur Parasitenkunde, 63, 101-111. doi: 10.1007/BF00927526.

Bellard C., Bertelsmeier C., Leadley P., et al., 2012. Impacts of climate change on the future of biodiversity. Ecol. Lett. 15:365-377. DOI: 10.1111/j.1461-0248.2011.01736.x

Bezerra J.C.B., Becker, W., Zelck, U.E., 1997. A comparative study of the organic acid content of the hemolymph of Schistosoma mansoni-resistant and susceptible strains of Biomphalaria glabrata. Mem. Inst. Oswaldo Cruz, 92,421- 425. http: //dx.doi.org/10.1590/S0074-02761997000300021.

Biswas C., Mandal C., 1999. The role of amoebocytes in the endotoxin-mediated coagulation in the innate immunity of Achatina fulica snail, Scand. J. Immunol. 49, 131-138.

Biswas C., Sinha D., Mandal C., 2000. Investigation on interaction of Achatinin, a 9-O-acetyl sialic acid-binding lectin, with lipopolysaccharide in the innate immunity of Achatina fulica snails. Mol Immunol. 37, 745-54.

Bonfim T.C.S., Tunholi-Alves, V.M., Martins, F.G., et al., 2018. Biological and histological changes in reproductive patterns of Biomphalaria glabrata experimentally co-infected by Echinostoma paraensei and Angiostrongylus cantonensis. Exp. Parasitology.195, 66-70.

Borrero F.J., Breure, A.S.H., Christensen, C., 2009. Into the Andes: Three new introductions of Lissachatina fulica (Gastropoda, Achatinidae) and its potential distribution in South America. Tentacle. 17,6-8.

Bose R., Bhattacharya S., 2000. C-reactive protein in the hemolymph of Achatina fulica: interrelationship with sex steroids and metallothionein. Comp Biochem Physiol A Mol Integr Physiol.125, 485-95.

Brockelman C.R., Sithithavorn, P., 1980. Carbohydrate reserves and hemolymph sugars of the African giant snail, Achatina fulica in relation to parasitic infection and starvation. Zeitschrift fur Parasitenkunde, 62, 285-91. doi: 10.1007/BF00926568.

Butcher A.R., Grove D.I., 2001. Description of the life-cycle stages of Brachylaima cribbi n. sp. (Digenea: Brachylaimidae) derived from eggs recovered from human faeces in Australia. Syst. Parasitol. 49, 211-221. 
Carvalho O.S., Teles, H.M.S., Mota, E.M. et al. 2003. Potentiality of Achatina fulica Bowdich, 1822 (Mollusca: Gastropoda) as intermediate host of Angiostrongylus costaricensis Morera and Céspedes, 1971. Revista Soc. Brasil. Med. Trop. 3,743-745.

Carvalho O.S., Scholte, R.G.C., Mendonça, CLF, Passos LKJ, Caldeira RL 2012. Angiostrongylus cantonensis (Nematode: Metastrongyloidea) in molluscs from harbour areas in Brazil. Mem. Inst. Oswaldo Cruz. 107,740-746.

Cavalcanti, M.G., Filho, F.C., Mendonca, A.M., Duarte, G.R., Barbosa, C.C., De Castro, C.M., Alves, L.C., Brayner, F.A., 2012. Morphological characterization of hemocytes from Biomphalaria glabrata and Biomphalaria straminea. Micron 43, 285-291.

Cheng T., Alicata J. 1965. On the mode of infection of Achatina fulica by the larvae of Angiostrongylus cantonensis. Malacologia. 2, 267-274.Civeyrel L., Simberloff D. 1996. A tale of two snails: is the cure worse than the disease? Biodivers. Conserv. 5,1231-1252.

Cognato, B.B., Morassuti, A., Silva, A.C.A., Graeff-Teixeira, C. 2016. First report of Angiostrongylus cantonensis in Porto Alegre, State of Rio Grande do Sul, Southern Brazil. Rev Soc. Brasil Med. Trop. 46, 664-665.

Combes C., 2000. Selective pressure in host-parasite systems. J Soc Biol. 194, 19-23.

Correoso R.M., 2006. Estrategia preliminar para evaluar y erradicar Achatina fulica (Gastropoda: Achatinaceae) em Ecuador. Boletim Tecnico IASA, Série Zoológica. 2, 45-52.

Cowie R.H. 2001. Can snails ever be effective and safe biocontrol agents? Int J Pest Manage. 47, $23-$ 40.

Cowie, R.H. 2013a. Eosinophilic meningitis caused by Angiostrongylus cantonensis, the rat lungworm: biology, distribution, epidemiology, detection, diagnosis, treatment, and management. Hawaii Journal of Medicine and Public Health. 72, 28-32.

De La Ossa-Lacayo, A.; De La Ossa, V.J.; Lasso, C.A. 2012. Registro del caracol africano gigante Achatina fulica (Bowdich 1822) (Mollusca: Gastropoda-Achatinidae) en Sincelejo, costa Caribe de Colombia. Biota Colombiana. 13, 247-252.

DeLeury E., Dubreuil G., Elangovan N., Wajnberg E., Reichhart J.M., Gourbal B., Duval D., Baron O.L., Gouzy J., Coustau C., 2012. Specific versus non-specific immune responses in an invertebrate species evidenced by a comparative de novo sequencing study. PLoS One. 7(3):e32512. doi: 10.1371/journal.pone.0032512.

Dheilly N.M., Adema C., Raftos D.A., Gourbal B., Grunau C., Du Pasquier L., 2014. No more nonmodel species: the promise of next generation sequencing for comparative immunology. Dev Comp Immunol. 45, 56-66. doi: 10.1016/j.dci.2014.01.022.

Di Cesare A., Crisi P.E., Bartolini R., et al., 2015. Larval development of Angiostrongylus vasorum in the land snail Helix aspersa. Parasitol. Res. 114, 3649-3655. doi: 10.1007/s00436-015-4592-y 
Di Noia J.M., Neuberger M.S., 2007. Molecular mechanisms of antibody somatic hypermutation. Annu. Rev. Biochem. 76,1-22.

Dróźdź J., Doby J.M., Mandahl-Barth G., 1971. Étude des morphologie et evolution larvaires de Angiostrongylus (Parastrongylus) dujardini Dróźdź et Doby, 1970 Nematoda: Metastrongyloidea. Infestation des mollusques hôtes intermédiares. Ann. Parasitol. Hum. Comp, 46, 265-276.

Druart C., Millet M., Scheifler R., et al., 2011. Snails as indicators of pesticide drift, deposit, transfer and effects in the vineyard. Sci Total Environ. 409, 4280-4288. doi:10.1016/j.scitotenv.2011.07.006

Ehara T, Kitajima S, Kanzawa N, Tamiya T, Tsuchiya T (2002). Antimicrobial action of achacin is mediated by L-amino acid oxidase activity. FEBS Lett, 531:509-512

E-Kobon T., Thongararm P., Roytrakul S., Meesuk L., Chumnanpuen P., 2015. Prediction of anticancer peptides against MCF-7 breast cancer cells from the peptidomes of Achatina fulica mucus fractions. Comput Struct Biotechnol J. 14, 49-57.

El-Ansary A., Sammour E.M., Mohamed A.M., 2000. Susceptibility of Biomphalaria alexandrina to infection with Schistosoma mansoni: correlation with the activity levels of certain glycolytic enzymes. J. Egypt Soc Parasitol. 30, 547-560.

Escoubas J-M., Destoumieus-Garzon D., Montagnani C., et al., 2015. Immunity in Molluscs. In: Ratcliffe MJH, ed. Encyclopedia of Immunology, Vol. 1. Oxford, UK: Oxford Academic Press, 417436.

Etm L.B., Aleruchi C., Obande G.A., 2016. Antibacterial Properties of Snail Mucus on Bacteria Isolated from Patients with Wound Infection. Brit Microbiol Res J. 11, 1-9.

Fraga A., Ribeiro L., Lobato M., Santos, V., Silva J.R., Gomes H., Moraes J.L.C., Menezes J.S., Logullo C.J., Campos E., Fonseca R.N., 2013. Glycogen and glucose metabolism are essential for early embryonic development of the red flour beetle Tribolium castaneum. Plos one, 8:e65125. doi: 10.1371/journal.pone.0065125.

Francisco, C.J., Hermida, M.A., Santos, M.J., 2010. Parasites and symbionts from Mytilus galloprovincialis (Lamark, 1819) (Bivalves: Mytilidae) of the Aveiro Estuary Portugal. J. Parasitol. 96, 200-205.

Finlay B.B., McFadden G., 2006. Anti-immunology: evasion of the host immune system by bacterial and viral pathogens. Cell. 124, 767-782.

Fontanilla I.K., Sta Maria I.M., Garcia J.R., Ghate H., Naggs F., Wade C.M., 2014. Restricted genetic variation in populations of Achatina (Lissachatina) fulica outside of East Africa and the Indian Ocean Islands points to the Indian Ocean Islands as the earliest known common source. PLoS One. 9 (9): e105151. doi: 10.1371/journal.pone.0105151

Galinier, R., Roger, E., Mone, Y., Duval, D., Portet, A., Pinaud, S., Chaparro, C., Grunau, C., Genthon, C., Dubois, E., Rognon, A., Arancibia, N., Dejean, B., Theron, A., Gourbal, B., Mitta, G., 
2017. A multistrain approach to studying the mechanisms underlying compatibility in the interaction between Biomphalaria glabrata and Schistosoma mansoni. PLoS Negl. Trop. Dis. http://dx.doi.org/10.1371/journal.pntd.0005398.

Ghosh J., Lun C.M., Majeske A.J., Sacchi S., Schrankel C.S., Smith L.C., 2011. Invertebrate immune diversity. Dev Comp Immunol. 35, 959-74. doi: 10.1016/j.dci.2010.12.009.

Graeff-Teixeira C., 2007. Expansion of Achatina fulica in Brazil and potential increase risk for angiostrongyliasis. Trans. Royal Soc.Trop. Med. Hyg. 101, 743-744.

Graeff-Teixeira C., Silva A.C., Yoshimura K., 2009. Update on eosinophilic eningoencephalitis and its clinical relevance. Clin. Microbiol. Rev. 22, 322-348.

Gomot-de Vaufleury A., Bispo A., 2000. Methods for Toxicity Assessment of Contaminated Soil by Oral or Dermal Uptake in Land Snails. 1. Sublethal Effects on Growth. Environ. Sci Technol 34:18651870. doi: 10.1021/es9907212.

Grewal P.S., Grewal S.K., Tan L., Adams B.J., 2003. Parasitism of molluscs by nematodes: types of associations and evolutionary trends. J. Nematol. 35,146-156.

Gorbushin A.M., Borisova E.A., 2015. Lectin-like molecules in transcriptome of Littorina littorea hemocytes. Dev Comp Immunol. 48, 210-20. doi: 10.1016/j.dci.2014.10.007.

Gorbushin A.M., 2019. Derivatives of the lectin complement pathway in Lophotrochozoa. Dev Comp Immunol. 94, 35-58. doi: 10.1016/j.dci.2019.01.010.

Gourbal, B., Therón, A., Grunau C., Durval D., Mitta, G., 2015. Polymorphic Mucin-Like Protein in Schistosoma mansoni, a Variabale Antigen and a Key Component of the Compatibility Between the Schistosome and Its Snail Host. Res. Prob, Cell Differenc. 57, DOI 10,1007/978-3-319-20819-0_4

GuoY., ZhangY., Liu Q., Huang Y., Mao G., Yue Z., Abe Z.M., Li J., Wu Z., Li S., Zhou X., Hu W., Xiao N., 2019. A chromosomal-level genome assembly for the giant African snail Achatina fulica. GigaScience, 8, 1-8. doi: 10.1093/gigascience/giz124

Gutiérrez Gregoric, D.E., Núnez, V., Vogler, R., Rumi, A. 2011. Invasion of the Argentinean Paranense rainforest by the giant African snail Achatina fulica. Amer. Malac. Bull. 29,135-137.

Hallman G.J., 2011. Phytosanitary Applications of Irradiation. Comprehen. Revi. Food Sci Food Safety. 10, 143-151. doi: 10.1111/j.1541-4337.2010.00144.x

Hallman G.J., 2016. Phytosanitary irradiation of the invasive herbivorous terrestrial snail Cornu aspersum (Stylommatophora: Helicidae). Florida Entomol. 99, 156-158.

Hanington P.C., Forys M.A., Dragoo J.W., Zhang S.M., Adema C.M., Loker E.S., 2010. Role for a somatically diversified lectin in resistance of an invertebrate to parasite infection. Proc Natl Acad Sci USA. 107, 21087-92. doi:10.1073/pnas.1011242107. 
He Z.P., Dai X.B., Zhang S., Zhi T.T., Lun Z.R., Wu Z.D., Yang T.B., 2016. Complete mitochondrial genome of the giant African snail, Achatina fulica (Mollusca: Achatinidae): a novel location of putative control regions (CR) in the mitogenome within Pulmonate species. Mitochondrial DNA A DNA Mapp Seq Anal. 27, 1084-5.doi: 10.3109/19401736.2014.930833.

Hoxha T., Crookes S., MacIsaac I., Chang X., Johansson M., Dick J.T.A., Nicolai A., MacIsaac H.J., 2019. Comparative feeding behaviour of native and introduced terrestrial snails tracks their ecological impacts. NeoBiota 47, 81-94. https://doi.org/10.3897/neobiota.47.35000

Hughes A.L., 2010. Origin and diversification of the L-amino oxidase family in innate immune defenses of animals. Bio Med Pub Immunog. doi:10.1007/s00251-010-0482-8

Janeway Jr., C.A., 1994. The role of microbial pattern recognition in self: non-self-discrimination in innate and adaptative immunity. In: Hoffmann, J.A., Janeway Jr., C.A., Natori, S. (Eds.), Phylogenetic Perspectives in Immunity: The Insect Host Defense, pp. 116-122.

Jansch S., Frampton G.K., Römbke J., et al., 2006. Effects of pesticides on soil invertebrates in model ecosystem and field studies: a review and comparison with laboratory toxicity data.

Joosse, J. The hormone molluscs, p. 89-140. In: Janfer, H; Dwner, R.G.H. (eds). Vertebrate Endocrinology, v.2. Academic Press, New York, 452p. 1988.

Joosse J., van Elk, R., 1986. Trichobilharzia ocellata: physiological characterization of giant growth, glycogen deposit and absence of reproductive activity in the intermediate snail host, Lymnaea stagnalis. Exp. Parasitol. 62, 1-13. doi:10.1016/0014-4894(86)90002-0.

Kamiya H., Muramoto K., Yamasaki M., 1986. Aplysianin-A, an antibacterial and antineoplasmic glycoprotein in the albumen gland of a sea hare, Aplysia kurodai. Experientia. 42, 1065-1067.

Karuthapandi M., 2010. Studies on the Hemocytes of Achatina fulica. Ind. J. Multi. Res. 6, 207 - 214.

Kawasaki, M., Delamare-Deboutteville, J., Dang, C., Barnes, A.C., 2013. Hemiuroid trematode sporocysts are undetected by hemocytes of their intermediate host, the ark cockle Anadara trapezia: potential role of surface carbohydrates in successful parasitism. Fish. Shellfish Immunol. 35, 19371947.

Kim, J.R., Hayes, K.A. Yeung, N.W., Cowie, R.H. 2014. Diverse gastropod hosts of Angiostrongylus cantonensis, the rat lungworm, globally and with a focus on the Hawaiian Islands. PLoS ONE 9, e94969.

Knobler S., Mahmoud A.A.F., Lemon S.M., et al., 2006. The impact of globalization on infectious disease emergence and control: exploring the consequences and opportunities: workshop summary. National Academies Press, Washington, DC Lavine MD, Strand MR (2002) Insect hemocytes and their role in immunity. Insect Biochem Mol Biol, 32, 1295-1309.

Kubota Y., Watanabe Y., Otsuka H., Tamiya T., Tsuchiya T., Matsumoto J.J., 1985. Purification and characterization of an antibacterial factor from snail mucus. Comp Biochem Physiol C. 82, 345-8. 
Lacchini A.H., Davies A.J., Mackintosh D., Walker A.J., 2006. Beta-1, 3-glucan modulates PKC signalling in Lymnaea stagnalis defence cells: a role for $\mathrm{PKC}$ in $\mathrm{H} 2 \mathrm{O} 2$ production and downstream ERK activation. J Exp Biol. 209, 4829-40.

Lange M.K., Penagos-Tabares F., Muñoz-Caro T., Gärtner U., Mejer H., Schaper R., Hermosilla C., Taubert A., 2017. Gastropod-derived haemocyte extracellular traps entrap metastrongyloid larval stages of Angiostrongylus vasorum, Aelurostrongylus abstrusus and Troglostrongylus brevior. Parasit Vectors. 10(1): 50.doi: 10.1186/s13071-016-1961-z.

Larson M.K., Bender R.C., Bayne C. J., 2014. Resistance of Biomphalaria glabrata 13-16-R1 snails to Schistosoma mansoni PR1 is a function of haemocyte abundance and constitutive levels of specific transcripts in haemocytes. Inter J Parasitol, 44, 343-353.

Laruelle, F., Molloy, D.P., Roitman, V.A., 2002. Histological analysis of trematodes in Dreissena polymorpha: their location, pathogenicity, and distinguishing morphological characteristics. J. Parasitol. 88, 856-863.

Le Clec'h W., Anderson T.J., Chevalier F.D., 2016. Characterization of hemolymph phenoloxidase activity in two Biomphalaria snail species and impact of Schistosoma mansoni infection. Parasit Vectors. 22, 9:32. doi:10.1186/s13071-016-1319-6.

Lie K.J., 1982. Swellengrebel lecture: Survival of Schistosoma mansoni and other trematode larvae in the snail Biomphalaria glabrata. A discussion of the interference theory. Trop Geogr Med. 34, 111-22.

Lima, M. G., Tunholi-Alves, V.M., Bonfim, T. C. S., Gaudêncio, F. N., et al., 2017. Effects of experimental Angiostrongylus cantonensis infection on the reproductive biology of Biomphalaria straminea and Biomphalaria tenagophila. J Invert Pathol.149, 106-113.

Lima M., Tunholi-Alves V.M., Gaudêncio F., Martins F., Castro N., Thiengo S.C., Garcia, J., Maldonado A., Pinheiro J., 2016. The influence of Angiostrongylus cantonensis (Nematoda, Metastrongylidae) infection on the aerobic metabolism of Biomphalaria straminea and Biomphalaria tenagophila (Mollusca, Gastropoda). J. Invert. Pathol. 171, 1-9.

Lindo, J. F. Waugh, C., Hall, J. et al., 2002. Enzootic Angiostrongylus cantonensis in rats and snails after an outbreak of human eosinophilicmeningitis, Jam Emer Infec Dis. 8, 324-326.

Livingstone, D.R., de Zwaan, A., 1983. Carbohydrate Metablismo of Gastropods, p. 177-242. In: Hochachka, P.W. (Ed). The Mollusca Metabolic Biochemistry and Molecular Biomechanics, v. 1. Academic Press, New York, 510p.

Loker E.S., Adema C.M., Zhang S.M., Kepler T.B., 2004. Invertebrate immune systems-not homogeneous, not simple, not well understood. Immunol Rev. 198, 10-24.

Loker, E.S., 2010. Gastropod immunobiology. Adv. Exp. Med. Biol. 708, 17-43. de Lorgeril, J., Zenagui, R., Rosa, R.D., Piquemal, D., Bachere, E., 2011. Whole transcriptome profiling of successful immune response to Vibrio infections in the oyster Crassostrea gigas by digital gene expression analysis. PLoS One 6, e23142. 
Loker E.S., Bayne C.J., 2018. Molluscan Immunobiology: Challenges in the Anthropocene Epoch. In: Cooper E. (eds) Advances in Comparative Immunology. Springer, Cham.

Lowe S., Browne M., Boudjelas S., De Poorter M., 2004. 100 of the World's Worst Invasive Alien Species A selection from the Global Invasive Species Database. The Invasive Species Specialist Group (ISSG) a specialist group of the Species Survival Commission (SSC) of the World Conservation Union (IUCN).

Lv S., Zhang Y., Steinmann P. et al. 2011. The emergence of angiostrongyliasis in the People's Republic of China: the interplay between invasive snails, climate change and transmission dynamics. Freshwater Biol. 56,717-734.

Mahilini, H.M., Rajendran, A., 2008. Categorization of hemocytes of three gastropod species Trachea vittata (Muller), Pila globosa (Swainson) and Indoplanorbis exustus (Dehays). J. Invertebr. Pathol. 97 , 20-26.

Maldonado, A.; Simões, R.O.; OLiveira, A.P.; Mota, E.M.; Fernadez, M.A.; Pereira, Z.M.; Monteiro, S.S.; Torres, E.J.; Thiengo, S.C., 2010. First report of Angiostrongylus cantonensis (Nematoda: Metrastrongylidae) in Achatina fulica (Mollusca: Gastropoda) from Southeast and South Brazil. Mem Inst Oswaldo Cruz. 105, p. 1-4.

Malek E.A., Cheng, T.C., 1974. Medical and economic malacology. New York. Ed. Academic Press, $382 p$.

Mandal C., Biswas M., Nagpurkar A., Mookerjea S., 1991. Isolation of a phosphoryl choline-binding protein from the hemolymph of the snail, Achatina fulica. Dev Comp Immunol. Fall. 15, 227-39.

Martins F.G., Lima M.G., Nora R.C., et al., 2018. Bulimulus tenuissimus (mollusca) as a new potential host of Angiostrogylus cantonensis (nematoda), a histological and metabolic study. J. Invert Pathol. $154,165$.

Martínez- Escarbassiere, R., Martínez, E. 1997. Nota acerca de la Achatina (Lissachatina) fulica (Bowdich,1822) peligroso caracol africano (Pulmonata- Achatinidae) introduzido en Venezuela. Acta Biol. Venezuélica. 17, 37-40.

Massa D.R., Chejlava M.J., Fried B., Sherma J., 2007. High performance column liquid chromatographic analysis of selected carboxylic acids in Biomphalaria glabrata patently infected with Schistosoma mansoni. Parasitol. Res. 101, 925-928. doi: 10.1007/s00436-007-0563-2.

Mead A., 1961. Helicid land mollusks introduced into North America. The Biologist. 104-111

Mitta G., Gourbal B., Grunau C., et al., 2017. The Compatibility Between Biomphalaria glabrata snails and Schistosoma mansoni. Advances Parasitol. 96, 111-145.

Mitra D., Sarkar M., 1988. A galactose specific agglutinin from the hemolymph of the snail Achatina fulica: purification and characterization. Dev Comp Immunol. 12, 33-42. 
763

764

765

766

767

768

769

770

771

772

773

774

775

776

777

778

779

780

781

782

783

784

785

786

787

788

789

790

791

792

793

794

795

796

Mitra D., Sarkar M., Allen A.K., 1988. Purification and characterization of an agglutinin from mucus of the snail Achatina fulica. Biochimie.70, 1821-9.

Mladineo, I., Petric, M., Hrabar, J., Bocina, I., Peharda, M., 2012. Reaction of the mussel Mytilus galloprovincialis (Bivalvia) to Eugymnanthea inquilina (Cnidaria) and Urastoma cyprinae (Turbellaria) concurrent infestation. J. Invertebr. Pathol. 110, 118-125.

Morassutti A.L., Thiengo S.C., Fernandez M. et al. 2014. Eosinophilic meningitis caused by Angiostrongylus cantonensis: an emergent disease in Brazil. Mem Inst Oswaldo Cruz. 109, 399-407.

Morera, P., 1973. Life history and redescription of Angiostrongylus costaricensis Morera and Céspedes, 1971, Am J Trop Med Hyg. 22, 613-21.

Mukherjee, K., Korithoski, B., Kolaczkowski, B., 2014. Ancient origins of vertebrate-specific innate antiviral immunity. Mol. Biol. Evol. 31, 140-153.

Müller V., de Boer R.J., Bonhoeffer S., Szathmáry E., 2017. An evolutionary perspective on the systems of adaptive immunity. Biol Rev Camb Philos Soc. 93, 505-528. doi: 10.1111/brv.12355.

Murthy M., Ram J. L., 2015. Invertebrates as model organisms for research on aging biology. Invert. Reprod. Develop. 59, No. S1, 1-4, http://dx.doi.org/10.1080/07924259.2014.970002

Netea MG, Quintin J, van der Meer JW (2011) Trained immunity: a memory for innate host defense. Cell Host Microbe 9: 355-361. doi: 10.1016/j.chom.2011.04.006 PMID: 21575907

Obara K., Otsuka-Fuchino H., Sattayasai N., Nonomura Y., Tsuchiya T., Tamiya T., 1992. Molecular cloning of the antibacterial protein of the giant African snail, Achatina fulica Férussac. Eur J Biochem. 209, 1-6.

Ogawa M., Nakamura S., Atsuchi T., Tamiya T., Tsuchiya T., Nakai S., 1999. Macromolecular antimicrobial glycoprotein, achacin, expressed in a methylotrophic yeast Pichia pastoris. FEBS Lett. 448, 41-4.

Oliveira J.L., Santos S.B., 2018. Distribution of cysts of Strongyluris sp. (Nematoda) in the palial system of Achatina fulica Bowdich, 1822 from Vila Dois Rios and Vila do Abraão, Ilha Grande, Angra dos Reis, Rio de Janeiro. Braz. J. Bio. 79, 38-44. doi: 10.1590/1519-6984.173449 Paraguay Biodiversidad. 2010. Gastropoda. Available at: http://www.pybio.org/201/gastropoda.

Otsuka-Fuchino H., Watanabe Y., Hirakawa C., Tamiya T., Matsumoto J.J., Tsuchiya T., 1992. Bactericidal action of a glycoprotein from the body surface mucus of giant African snail. Comp Biochem. Physiol. 101C, 607-613.

Otsuka-Fuchino H., Watanabe Y., Hirakawa C., Takeda J., Tamiya T., Matsumoto J.J., Tsuchiya T., 1993. Morphological aspects of achacin-treated bacteria Comp. Biochem. Physiol. 104C, 37-42.

Peiser, L., Mukhopadhyay, S., Gordon, S., 2002. Scavenger receptors in innate immunity. Curr. Opin. Immunol. 14, 123-128. 
Penagos-Tabares F., Lange M.K., Seipp A., Gärtner U., Mejer H., Taubert A., 2018. Hermosilla C. Novel approach to study gastropod-mediated innate immune reactions against metastrongyloid parasites. Parasitol Res. 117, 1211-1224. doi:10.1007/s00436-018-5803-0.

Perrin C., Lepesant J.M., Roger E., Duval D., Fneich S., Thuillier V., Alliene J.F., Mitta G., Grunau C., Cosseau C., 2013. Schistosoma mansoni mucin gene (SmPoMuc) expression: epigenetic control to shape adaptation to a new host. PLoS Pathog. 9(8): e1003571. doi: 10.1371/journal.ppat.1003571.

Pinheiro J., Amato S.B., 1994. Eurytrema coelomaticum: influence of the infection on the reproduction and nucleic acids contents in the albumen gland and ovotestis of Bradybaena similaris. Mem. Inst. Oswaldo Cruz. 90, 635-638. doi: 10.1590/S0074-02761995000500019

Pinheiro J., Amato S.B., 1994. Eurytrema coelomaticum (Digenea, Dicroceliidae): the effect of infection on carbohydrate contents of its intermediate snail host, Bradybaena similaris (Gastropoda, Xanthnychidae). Mem. Inst. Oswaldo Cruz. 89,407-410. http://dx.doi.org/10.1590/S0074$\underline{02761994000300020 .}$.

Pinheiro J., Maldonado A., Lanfredi R.M., 2009. Physiological changes in Lymnaea columella (Say, 1818) (Mollusca, Gastropoda) in response to Echinostoma paraensei Lie and Basch, 1967 (Trematoda, Echinostomatidae) infection. Parasitol. Res. 106, 55-59. doi: 10.1007/s00436-009- 1630-7

Pinaud, S., Portela, J., Durval, D., Nowacki, F.C., Olive, M.A., Allienne, J.F., Galinier, R., Dheilly, N.M., Kieffer-Jaquinod, S., Mitta, G., Theron, A., Gourbal, B. (2016). A shift from cellular to humoral response contributes to innate immune memory in vector snail Biomphalaria glabrata. PLoS Pathog. 12 , e1005361.

Poirier, A.C., Schmitt, P., Rosa, R.D., Vanhove, A.S., Kieffer-Jaquinod, S., Rubio, T.P., Charriere, G.M., Destoumieux-Garzon, D., 2014. Antimicrobial histones and DNA traps in invertebrate immunity: evidences in Crassostrea gigas. J. Biol. Chem. 289, 24821-24831.

Prociv P., Spratt D.M., Carlisle M.S. 2000. Neuro-angiostrongyliasis: unresolved issues. Int J Parasitol. 30,1295-1303.

Queiroga, F.R., Marques-Santos, L.F., Hegaret, H., Soudant, P., Farias, N.D., Schlindwein, A.D., Mirella Da Silva, P., 2013. Immunological responses of the mangrove oysters Crassostrea gasar naturally infected by Perkinsus sp. in the Mamanguape Estuary, Paraiba state (Northeastern, Brazil). Fish Shellfish Immunol. 35, 319-327.

Raccurt C.P., Blaise J., Durette-Desset M.C. 2003. Présence d'Angiostrongylus cantonensis en Haïti. Trop Med Int Health. 8, 423-426.

Rae, R., 2017. The gastropod shell has been co-opted to kill parasitic nematodes. Sci Rep 7, 4745 doi:10.1038/s41598-017-04695-5.

Raut S.K., Barker G.M., 2002. Achatina fulica Bowdich and other Achatinidae as pests in tropical agriculture, in: Barker GM (Ed) Molluscs as crop pests. CABI, Wallingford, 55-114 pp. 
Ray, M., Bhunia, A.S., Bhunia, N.S., Ray, S., 2013. Density shift, morphological damage, lysosomal fragility and apoptosis of hemocytes of Indian molluscs exposed to pyrethroid pesticides. Fish Shellfish Immunol. 35, 499-512.

Rekha S.R., Munsi M., Neelavara A.A., 2015. Effect of Climate Change on Invasion Risk of Giant African Snail (Achatina fulica Férussac, 1821: Achatinidae) in India. PLOS ONE 10: e0143724. doi: 10.1371/journal.pone.0143724

Richards C.S., Merritt J.W. 1967. Studies on Angiostrongylus cantonensis in molluscan intermediate hosts. J. Parasitol. 53, 382-388.

Richardson D. M., Pyšek P., Rejmánek M., Barbour M. G., Panetta D. F., West C. J., 2000.Naturalization and invasion of alien plants: concepts and definitions. Divers. Distrib. 6, 93-107. doi:10.1046/j.1472-4642.2000.00083.x

Richardson D. M., Pysek P., 2006. Plant invasions: merging the concepts of species invasiveness and community invasibility. Prog. Phys. Geogr.30, 409-431. doi:10.1191/0309133306pp490

Robinson D.G., 1999. Alien invasions: the effects of the global economy on non-marine gastropod introductions into the United States. Malacologia. 41,413-438.

Roda A., Nachman G., Weihman S., et al., 2016. Reproductive Ecology of the Giant African Snail in South Florida: Implications for Eradication Programs. PLOS ONE 11: e0165408. doi: 10.1371/journal.pone.0165408

Ruiz G.M., Carlton J.T., 2003. Invasive species: vectors and management strategies. (Eds) Island Press, Washington, DC.

Saadi A.J., Wade C.M., 2019.Resolving the basal divisions in the stylommatophoran land snails and slugs with special emphasis on the position of the Scolodontidae. Mol Phylog Evol. 139pp. 106529dx.doi.org/10.1016/j.ympev.2019.106529

Sarkar M., Bachhawat B.K., Mandal C., 1984. A new cold agglutinin from Achatina fulica snails. Arch Biochem Biophys. 233, 286-9.

Salawu M.O., Oloyede O.B., Oladiji A.T., Muhammad N.O., Yakubu M.T., 2011. Effect of Escherichia coli endotoxin on Archachatina marginata hemolymph coagulation system. Pharm Biol. 49, 1029-33. doi: 10.3109/13880209.2011.560952.

Sarrias, M.R., Gronlund, J., Padilla, O., Madsen, J., Holmskov, U., Lozano, F., 2004. The scavenger receptor cysteine-rich (SRCR) domain: an ancient and highly conserved protein module of the innate immune system. Crit. Rev. Immunol. 24, 1-37.

Schmitt, P., Duperthuy, M., Montagnani, C., Bachere, E., Destoumieux-Garzon, D., 2011. Immune responses in the Pacific oyster Crassostrea gigas. An overview with focus on summer mortalities. In: QIN, J. (Ed.), Oysters: Physiology, Ecological Distribution and Mortality. Nova Publishers. Schuster R., Neumann B., 1988. Seasonal occurrence of Dicrocoelium dendriticum in intermediate hosts. Angew. Parasitol. 29, 31-36. 
Sen G., Mandal C., Chowdhury M., 1992. Albumen gland of the snail Achatina fulica is the site for synthesis of AchatininH, a sialic acid binding lectin. Mol Cell Biochem. 18, 133-8.

Shih H.H., Chen S.N., 1982. Glycolytic enzymes in juvenile and adult Angiostrongylus cantonensis. South. Asian J. Trop. Med. Public Health. 13, 114-119.

Schultz J.H., Adema C.M., 2017. Comparative immunogenomics of molluscs. Dev Comp Immunol. 75:3-15. doi: 10.1016/j.dci.2017.03.013.

Schultz J.H., Bu L., Adema C.M., 2018. Comparative immunological study of the snail Physella acuta (Hygrophila, Pulmonata) reveals shared and unique aspects of gastropod immunobiology. Mol Immunol. 101, 108-119.

Sirrad, J.C., Vignal, C., Dessein, R., Chamaillard, M., 2007. Nod-like receptors: cytosolic watchdogs for immunity against pathogens. PLoS Pathog. 3, e152.

Soen Y., 2014. Environmental disruption of host-microbe co-adaptation as a potential driving force in evolution. Frontiers in Genetics, 5, 168. DOI=10.3389/fgene.2014.00168

Spratt D.M., 2015. Species of Angiostrongylus (Nematoda: Metastrongyloidea) in wildlife: A review. Int J Parasitol Parasites Wildl. 4, 178 - 89. doi: 10.1016/j.ijppaw.2015.02.006

Suwannapan W., Chumnanpuen P., E-Kobon T., 2018. Amplification and bioinformatics analysis of conserved FAD-binding region of L-amino acid oxidase (LAAO) genes in gastropods compared to other organisms. Comput Struct Biotechnol J. 16, 98-107.

Takamatsu N., Shiba T., Muramoto K., Kamiya H., 1995. Molecular cloning of the defense factor in the albumen gland of the sea hare Aplysia kurodai. FEBS Lett. 377, 373-376.

Teles H.M.S., Fontes L.R. 2002. Implicacões da introdução e dispersão de Achatina fulica Bowdich, 1822 no Brasil. Boletim Inst Adolfo Lutz. 12, 3-5.

Thiengo S.C., Faraco F.A., Salgado N.C. et al.2007. Rapid spread of an invasive snail in South America: the giant African snail, Achatina fulica, in Brasil. Biol. Invasions. 9, 693-702.

Thiengo S.C., Maldonado A., Mota E.M. et al. 2010. The giant African snail Achatina fulica as natural intermediate host of Angiostrongylus cantonensis in Pernambuco, northeast Brazil. Acta Trop. 115, 194-199.

Thiengo S.C., Fernandez M.A., 2013. Gastrópodes neotropicais continentais de importância médica. In: Dinâmica das Doenças Infecciosas e Parasitárias (JR Coura, Org.), $2^{\text {a }}$ ed., Rio de Janeiro, Guanabara Koogan: 131-140.

Thiengo, S.C., Fernandez, M.A., 2016. Moluscos como Hospedeiros intermediários de Angiostrongylus cantonensis en Brasil. In Angiostrongylus cantonensis: Emergencia en America. Robles, LM and Dorta-Contreras, AJ Eds., Editorial Academia, Cuba, 280 pp.

Tonegawa S., 1983. Somatic generation of antibody diversity. Nature, 2(5909),575-581. 
Tunholi, V.M., Lustrino, D., Tunholi-Alves, V.M., Mello-Silva, C.C., Maldonado, A., Pinheiro, J., Rodrigues, M.L.A., 2011. Biochemical profile of Biomphalaria glabrata (Mollusca: Gastropoda) after infection by Echinostoma paraensei (Trematoda: Echinostomatidae). Parasitol. Res. 109, 885-891. http://dx.doi.org/10.1007/s00436-011-2330-7.

Tunholi V.M., Tunholi-Alves V.M., Lustrino D., Castro R.N., Garcia J., Maldonado A., Dos Santos M., Rodrigues M.L.A., Pinheiro J., 2013. Aerobic to anaerobic transition in Biomphalaria glabrata (Say, 1818) infected with different miracidial doses of Echinostoma paraensei (Lie and Basch, 1967) by high-performance liquid chromatography. Exp. Parasito. 133, 403-410.

Tunholi-Alves V.M., Tunholi V.M., Castro R,N., Sant'ana L., Amaral L., Garcia J., Oliveira A.M., Maldonado A., Thiengo S.C., Pinheiro J., 2014. Activation of anaerobic metabolism in Biomphalaria glabrata (Mollusca:Gastropoda) experimentally infected by Angiostrongylus cantonensis (Nematoda, Metastrongylidae) by high-performance liquid chromatography.Parasitol. Inter. 63, 64-68.

Tunholi-Alves V.M., Tunholi V.M., Gracia J., Mota E., Castro R., Pontes E., Pinheiro J., 2018. Unveiling the oxidative metabolism of Achatina fulica (Mollusca:Gastropoda) experimentally infected to Angiostrongylus cantonensis (Nematoda: Metastrongylidae). Parasitol. Research, 117, 1773-1781.

Turner G.J., 1967. Snail transmission of species of Phytophthora with special reference to foot rot of piper nigrum. Trans. British Mycol. Soc, 50, 251-258. doi: 10.1016/S0007-1536(67)80035- 4

van der Knaap W.P., Sminia T., Schutte R., Boerrigter-Barendsen L.H., 1983. Cytophilic receptors for foreignness and some factors which influence phagocytosis by invertebrate leucocytes: in vitro phagocytosis by amoebocytes of the snail Lymnaea stagnalis. Immunol. 48, 377-83.

Vogler, R.E., Beltramino, A.A., Sede, M.M. et al., 2013. The giant African snail, Achatina fulica (Gastropoda: Achatinidae): using bioclimatic models to identify South American áreas susceptible to invasion. Amer. Malac. Bull. 31, 39-50.

Wade C., Mordan P., Naggs F., 2006. Evolutionary relationships among the Pulmonate land snails and slugs (Pulmonata, Stylommatophora). Biol J Linnean Society, 87, 593-610.

Wallace G.D., Rosen, L., 1969a. Studies on eosinophilic meningitis: Experimental infection of rats and other homeothermic vertebrates with Angiostrongylus cantonensis. Am. J. Epidemiol.89, 331.

Wallace G.D., Rosen L., 1969c. Experimental infection of Pacific island mollusks with Angiostrongylus cantonensis. Am J Trop Med Hyg 18, 13-19.

Wang, L., Yang, J., Zhang, H., Huang, M., Kong, P., Zhou, Z., Song, L., 2012. A multi-CRD C-type lectin with broad recognition spectrum and cellular adhesion from Argopecten irradians. Dev. Comp. Immunol. 36, 591-601.

Wang J., Wang L., Yang C., Jiang Q., Zhang H., et al., 2013. The response of mRNA expression upon secondary challenge with Vibrio anguillarum suggests the involvement of C-lectins in the immune priming of scallop Chlamys farreri. Dev. Comp. Immunol. 40, 142-147. DOI: 10.1016/j.dci.2013.02.003 PMID: 23434464 
Williams A.J., Rae R., 2015. Susceptibility of the Giant African snail (Achatina fulica) exposed to the gastropod parasitic nematode Phasmarhabditis hermaphrodita. J. Invert. Pathol. 127, 122-126. doi: 10.1016/j.jip.2015.03.012

Williams, A. and Rae, R., 2016. Cepaea nemoralis uses its shell as a defence mechanism to trap and kill parasitic nematodes. J. Mollus. Stud. 12, 1-2.

Wootton, E.C., Dyrynda, E.A., Ratcliffe, N.A., 2006. Interaction between non-specific electrostatic forces and humoral factors in haemocyte attachment and encapsulation in the edible cockle, Cerastoderma edule. J. Exp. Biol. 209, 1326-1335.

Yoneyama, M., Fujita, T., 2007. RIG-I family RNA helicases: cytoplasmic sensor for antiviral innate immunity. Cytokine Growth Factor Rev. 18, 545-551.

Yoshino T.P., 1976. The ultrastucture of the circulating hemoymph cell of the marine snail Cerithidea californica (Gastropoda: Prosobranchia). J. Morph. 150, 485.

Zanker K.S., 2010. Immunology of Invertebrates: Humoral. Encyclopedia of Life Sciences John Wiley and Sons, Ltd: Chichester.

Zanol J., Fernandez M.A., Oliveira A.P.M., et al., 2010. O caramujo exótico invasor Achatina fulica (Stylommatophora, Mollusca) no Estado do Rio de Janeiro (Brasil): situação atual. Biota. Neotro. 10, 447-451. doi: 10.1590/S1676-06032010000300038

Zhang S.M., Adema C.M., Kepler T.B., Loker E.S., 2004. Diversification of Ig superfamily genes in an invertebrate. Science. 305, 251-4.

Zhong J., Wang W., Yang X., Yan X., Liu R., 2013. A novel cysteine-rich antimicrobial peptide from the mucus of the snail of Achatina fulica. Peptides. 39:1-5. 


\section{Highlights}

- The giant African snail Achatina fulica, the most widely distributed invasive pest land snail, will likely disperse further with climate change.

- Achatina fulica is intermediate host for the nematode Angiostrongylus cantonensis that causes eosinophilic meningitis.

- Study of metabolic and immunological aspects of this parasite host provide better understanding of epidemiology and inform on comparative immunology of gastropods 